Human Ethology 35 (2020) (Suppl.) https://doi.org/10.22330/he/35/suppl

\title{
Human EThology SPECIAl SUPPLEMENT TO HONOUR Bill CHARLESWORTH
}

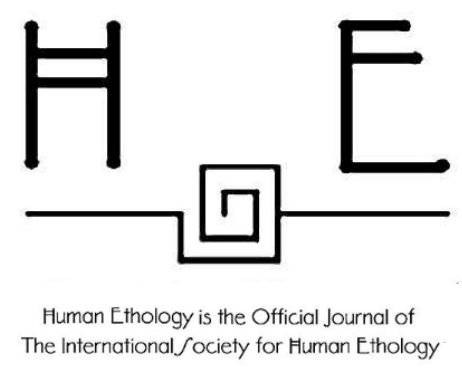




\section{WELCOME}

\section{Colin Hendrie}

Editor in Chief

C.A.Hendrie@leeds.ac.uk

Human Ethology are delighted to be able to publish this special supplement in honour of ISHE co-founder and former President Bill Charlesworth. The supplement contains contributions from long-standing ISHE member Carol Weisfeld, and former ISHE Presidents Glenn Weisfeld and Peter LaFreniere. Readers are also encouraged to look at Human Ethology Bulletin, 33 (3), 27-33 (2018), a piece by Bill himself about Irenäus Eibl-Eibesfeldt as this gives further insight into the mutual respect, warmth and friendships that gave rise to ISHE being formed. 


\title{
About Bill Charlesworth
}

\author{
Carol Weisfeld 1 and Glenn Weisfeld ${ }^{2}$ \\ 1University of Detroit Mercy, Detroit, USA \\ 2Department of Psychology, Wayne State University, Detroit, USA \\ weisfecc@udmercy.edu
}

This will be a trip back in time. I ask the reader to look at the 3 attached photos, from August of 2000, at the ISHE meeting in Salamanca, Spain.

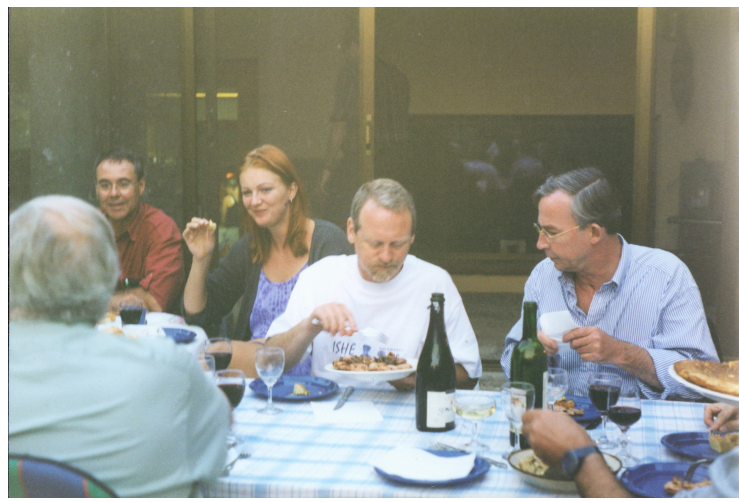

Picture 1: Meeting in Slamanca, 2000. Left-to-right: F. Abati, A. Juette, P. LaFreniere, J. van der Dennen. Photo by Carol Weisfeld
I believed that the weather was incredibly hot; but that was normal for late summer in Salamanca, the oldest university town in Spain, as the residents explained to us visitors. We were lucky to be dinner guests at the home of Dr. Francisco (Paco) Abati, who is the person on the left in photo $\# 1$, wearing a red shirt and smiling at Bill Charlesworth, whose back faces the camera. Paco hosted 20 of us at his lovely home on one of the first nights of the conference. The wine flowed and the gourmet dishes just kept coming. In photo \#1, Astrid Juette is

also amused by something that Bill is saying. Peter LaFreniere, next to Astrid, is Bill's former student and apparently no longer feels the need to listen to Bill; Peter is focused on conversation with Johann van der Dennen.

In photo \#2, we get a profile of Bill Charlesworth, reaching for more chunks of lemon to go with the seafood dish, and talking at the same time. On his left is Linda Mealey, (whose face is not visible, but whose reddish-brown hair is easy to recognize), conversing with Nancy Segal and Dori LeCroy.

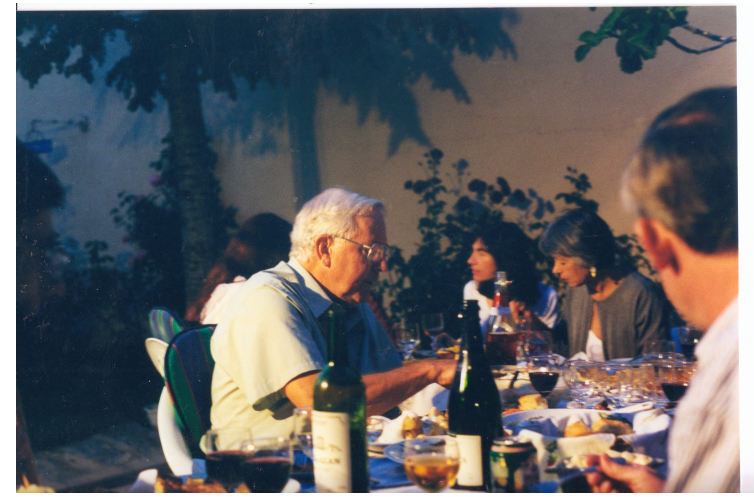

Picture 2: Meeting in Slamanca, 2000. Left-to-right: B. Charlesworth, L. Mealey, N. Segal, D. LeCroy. Photo by Carol Weisfeld 


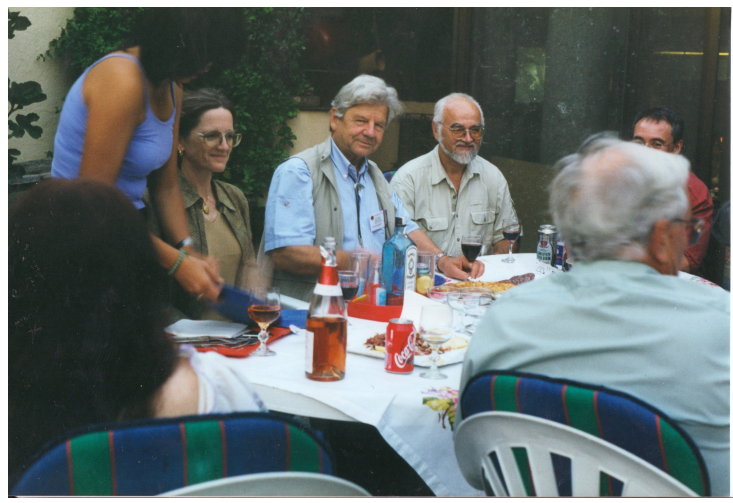

Picture 3: Meeting in Slamanca, 2000. Left-to-right: Unidentified guest, I. Eibl-Eibesfeldt, J. Panksepp, F. Abati. Photo by Carol Weisfeld
Photo \#3 gives us the view from behind Bill and Linda, looking at Irenaeus (Renki) Eibl-Eibesfeldt, and Jaak Panksepp, and, again, Paco. We have come full circle around the table. From this vantage point, Renki and Jaak both seem totally engaged by something that Bill is saying. They are in all likelihood preparing rejoinders, being drawn into a good-natured debate fueled by beer and wine. Some of these people are treasured memories for us, now, as we recall our good fortune to have spent time in the company of Linda, Renki, Jaak, and Johann.

Bill is still with us, luckily, and we are privileged to be part of a living circle of memory that includes him. And, rather than writing about Bill's fascinating research and his important theoretical work, I am writing a sort of social diary or gossip column, with no apologies. He was the social center of our ethological gatherings (some say that Bill was our social glue), and we still benefit from the legacy of his ability to bring us together. In these photos we see people from several countries and multiple time zones, people with competing goals and approaches to the work of understanding behavior. Paco provided the food and drink that night; Bill, as always, provided the open heart and full-throated joy at seeing each and every one of us. He joked and cajoled and made fun of himself - in several different languages, to everyone's amusement. He could bring even the most shy person into the limelight, by telling funny stories from years before, about his encounters with all of us, over the years. When he talked about his research, he presented it filled with hilarity. He regaled us with his stories and lovingly encouraged us to know one another better as people, as friends.

I remember so clearly that very morning, on the day of this dinner. I was having breakfast at the hotel with Linda Mealey, one of the finest observers of human behavior that I have ever known in my life. She sat across from me and watched my face as I said hello to people who greeted me and whom Linda could not see because they stood behind her. At one point she laughed out loud and said, "Carol, your face just lit up. I love it! Who is it that you are so happy to see this morning?" It was Bill Charlesworth. 


\title{
INTERVIEW OF BILL CHARLESWORTH
}

\author{
Peter LaFreniere \\ Professor Emeritus, Department of Psychology, University of Maine \\ peter@bluehillbaygallery.com
}

I got an MA on comparative/experimental psychology at Wesleyan University in Conn. Did research on behaviour genetics, exploratory behaviour in rats, effect of prenatal shock on offspring, early experience, phylogenesis - a great introduction to a wide range of disciplines. Then a $\mathrm{PhD}$ at Cornell for a $\mathrm{PhD}$ in developmental child psychology which included physiological psychology, cognition, family, and general development. My mentors there recommended I read Piaget and Tinbergen.

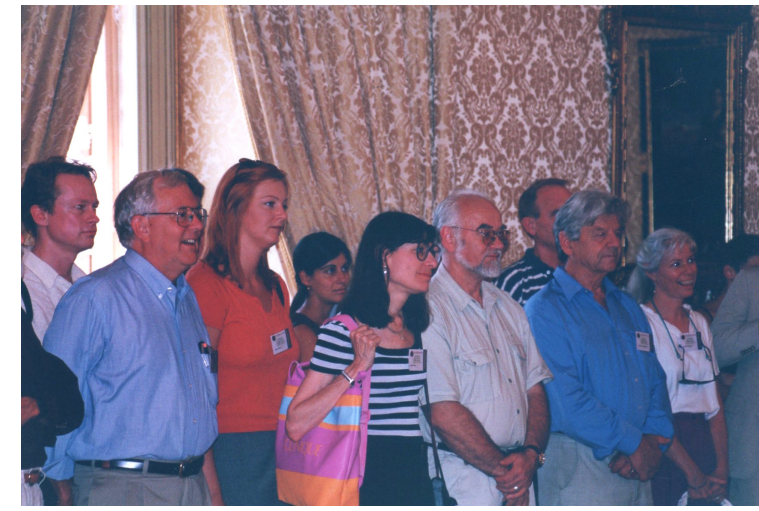

Picture 4: ISHE group at Salamanca, Spain in August, 2000, including Bill Charlesworth, Astrid Juette, Nancy Segal, Jack Panksepp, I. Eibl- Eibesfeldt. Photo by Peter LaFreniere

So I did, starting with Piaget and did a $\mathrm{PhD}$ on children's understanding of various spatial transformations of objects. I also liked Tinbergen's ideas, but instincts were very unpopular at that time. I realized, though, that some day time in my career I would have to take ethology serious.

Then off to U. of Minnesota as a developmental psychologist. After four years I met Eibl when he was visiting Minnesota and got immediately interested in his work and the ideas behind it. After that, I sought every chance to get to the Max Planck Institute in the Munich area. I succeeded in getting to MPI in Psychiatry in 1968 because at that time Seewiesen was heavily into non-human research (water fowl) and Eibl was spending much time then in the field. Detlev Ploog was the director of MPI of Psychiatry then. I lucked out because he was (is) a very bright guy with broad training in neurophysiology, language, primate behaviour and observation. And he saw ethology for what it was. A powerful science of behaviour. Actually, I spent two sabbatics in Munich. 
MPI had a great influence on me - struck me as a place for serious research, concern with a behavior, cross-disciplinary emphases... no struggle with students, teaching, committees and a lot of interesting minds walking around. While there I met Lorenz and other ethologists who took basic research seriously enough to invest much time in basic work such as descriptions and documentation - tedious, grinding work but worth it in the long run. Eibl is a good example.

On one of my visits to Eibl, he, Mario von Cranach, Paul Ekman, and I met and thought it was time to form some kind of international organisation of human ethology. We all felt such an organisation was necessary, but the problem was no one wanted to be its president. We all preferred research over administration. After much discussion, Eibl took it over in 1972 which I guess we can say is the date ISHE got formally started.

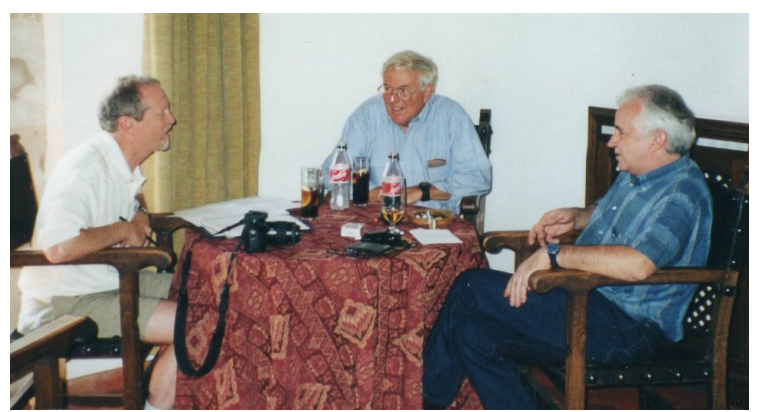

Picture 5: Informal meeting between HEB editor, Peter LaFreniere, Former ISHE president, Bill Charlesworth, and ISHE secretary, Karl Grammer. Photo by Astrid Juette.

Our first meeting was a modest workshop at the University of Minnesota which was attended by about twelve of us - German, Canadian, and American. A larger group met about a year later at Percha, and, a year later after that we had a meeting in London with Nick Blurton Jones. Also, at that time, we had several meetings with Dan Freedman's team in Chicago and also with Fred Strayer's team in Montreal. We were still a small group, at most 20-25 of us, some faculty, quite a few students - Don Omark, Bob Marvin, Glenn Weisfeld were big players.

During this time, I was at Minnesota struggling with teaching and research on object concept in infants and developing a surprise paradigm for assessing whether a child had the concept or not. I went with Eibl to Hannover, Germany, where he was studying behaviour on congenitally deaf/blind children trying to find out whether their facial expressions were like sighted children. They were. I did my surprise study there and discovered that their surprise reactions were no different from those of sighted children.

In subsequent work I continued to focus heavily on recording behaviour on film, video tape, and then analysing it. The fact that filmed records could be repeated for checks on reliability, for developing new and, chucking out old, behaviour categories, for fresh insights and additional hypothesis testing, and for posterity struck me as ideal. Also, did much field observation of children in various settings. I wasn't looking then for statistically significant findings to please the research power. I just wanted to construct a scheme for obtaining "meaningful" behaviour units by including everything we captured on film.

This experience raised an interesting question of how molecular or fine-grained behaviour scientists should get, especially when analysing social behavior. You know, behaviour records on film and video tape may contain much detail that isn't picked up socially so it may not be worth the time to microanalyses them when studying social 
interactions. But this is an empirical question which I thin still has to be answered by researchers such as Karl Grammer.

As for ignoring field observation and documentation of behavior. Think about it. Where would chemistry be without its long history of collecting and experimenting with materials, all the stuff on and under the ground, accumulating of toms of samples? This emphasis on observation/description as one of ethology's distinctive features led me relentlessly to my course motto:

\section{Follow the duck, not your theory of the duck}

This is the empiricist talking - I push this not only because I think we have sufficient objective and comprehensive evidence for our constructs that have to do with what people do everyday but also because we need to expunge from our minds that illusion that we know enough about humans and that we can therefore attempt to explain their behavior by evoking evolutionary theory. That's one reason I think that the field work being done at Vienna by ethologists such as Grammer or by Salter's field with Butovskaya on Russian streets or Adang's work on urban rioting.

Of course, critics may say, this work can be done by social psychologists. But not so. It is the evolutionary theoretical framework that ethnologist use to formulate hypotheses and seek answers to questions that makes it approachable to other behavioural approaches.

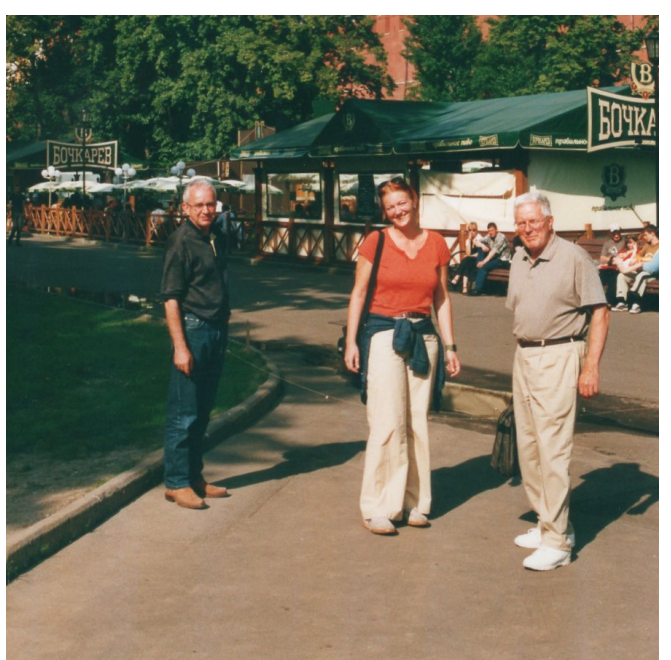

Picture 6: Karl Grammer, Astrid Juette \& Bill Charlesworth, Moscow Summer School, June, 2001. Photo by Peter LaFreniere.

Also, what many of us tend to forget is that ethology can play a major role in applied science. At Minnesota we developed behaviour coding schemes that would help educators and parents in assessing what was going on in the classroom and home setting. I can't see how any successful behaviour interventions can work without field observation. The behaviour modification guys knew this very well and developed behaviour/response schemes that turned out to be successful in helping educators and therapists manage behaviour problems etc.

As for any contributions I have made, I can think of three - (1) I developed a paradigm to use surprise reactions as indicators of cognitive structures and as motivators of epistemic curiosity, (2) I developed a scheme for observing and measuring intelligent behaviour (called PROBA - problem behavior analysis). This is an addition to intelligence tests which measure intelligence as a disposition. Focusing on behavior is ethological. And (3) I came up with the idea that much of cooperative behaviour is actually competition for resources and, as you well know since you worked with me on research, developed a way to elicit and measure cooperative/competitive behavior in kids ... thousands of kids worldwide. 


\title{
A Tribute to William R. Charlesworth
}

\author{
Peter LaFreniere \\ Professor Emeritus, Department of Psychology, University of Maine \\ peter@bluehillbaygallery.com
}

William R. Charlesworth, co: founder of ISHE and one of its former Presidents, was a central force in ISHE for over 40 years, from its inception to his recent retirement. Presently, he still lives with his wife Maria in Minnesota. For those who knew him well during this period and especially for those who did not, I'd like to offer this synopsis of his career from the point of view of his former student.

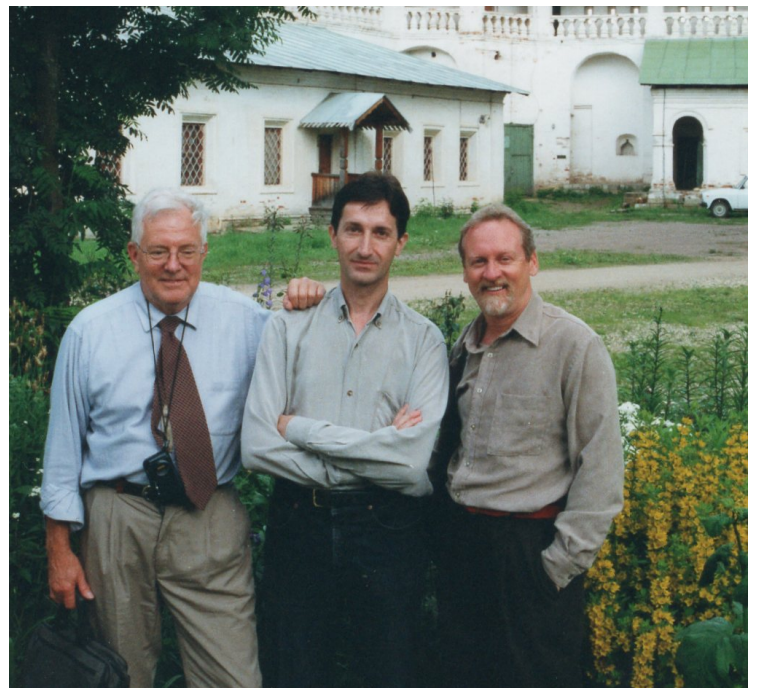

Picture 8: Bill Charlesworth, Peter LaFreniere \& Bernhard Thierry, Zvenigorod, Rusiia, June, 2001. Photographer unknown.

Before pursuing graduate training in comparative and developmental psychology, Bill had an interesting period serving in military intelligence in Germany from 1953-56. During this time he became fluent in German and married his German wife, Maria, who has been by his side ever since. I mention this because Bill's fluency in German would play a vital role in his academic career and the founding of ISHE, as you will see.

Bill earned his Ph.D. in developmental psychology at Cornell University in 1962 and was hired as a young Assistant Professor at the prestigious Institute of Child Development (ICD), University of Minnesota. Early in his career, Bill concentrated on experimental research with young children. He published three important articles in the flagship journal of his discipline, Child Development, which earned him tenure at ICD in 1966 (Charlesworth, 1964, 1966, 1966). This first phase of his career climaxed with an influential article on the role of surprise in cognitive development in a book honoring Jean Piaget. 
After this we see a major shift. His next 45 publications from 1973 to 2005 all deal with Human Ethology. What happened?

Irenäus Eibl-Eibesfeldt happened. A key stimulus was Eibl's first talk at the University of Minnesota in 1965. The ICD Director, Harold Stevenson, had invited a speaker from Germany and thought because Bill spoke fluent German he would be just the guy to show him around campus during his visit. Bill was intrigued with this Ethologist and the possibilities of studying real-world adaptation in young children. Besides, he wanted to practice his German.

That first talk at Minnesota was such a success that Bill arranged for Eibl to return to teach a course on Human Ethology that was a hit with both students and faculty. By this time Bill and Eibl were becoming close friends, and Eibl invited him on a field trip to the Galapagos Islands (see tribute to Eibl-Eibesfeldt, HEB (33),3, 2018). In 1968 Bill joined Eibl for a year as visiting Professor, at the Max Planck Institute of Psychiatry, Munich, Germany. A few years later, Bill organized the first international meeting at Minnesota in 1972 of a small, but enthusiastic, band of human ethologists including Bill, Eibl, Dan Freedman, etc. and their students. They elected Eibl-Eibesfeldt as their first President and ISHE was on its way. Suddenly there followed an avalanche of exciting empirical publications consisting largely of direct observation of human social interaction by a diverse group of German, Austrian, British, American and Canadian human ethologists. Bill was one of the researchers at the forefront of this sudden burst that energized

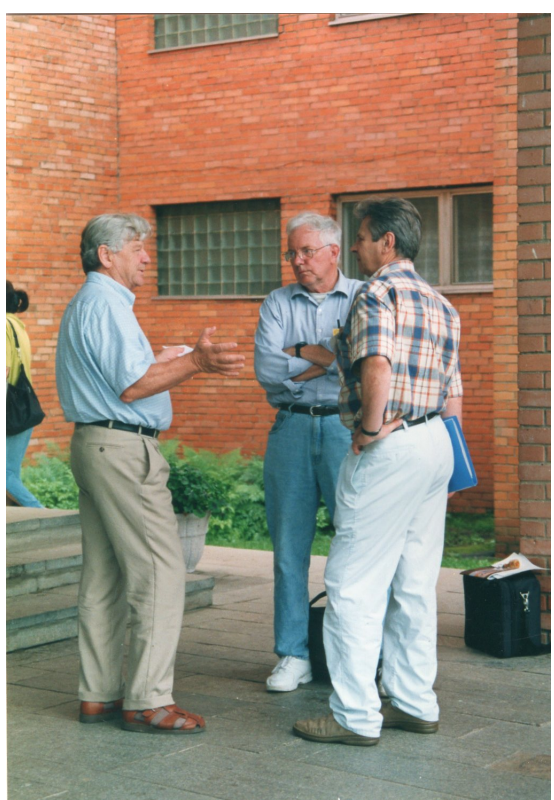

Picture 10: Professors Eibl-Eibesfeldt, Charlesworth and Tishkov in conversation at Zvenigorod, Russia. Originally published 2001 in Human Ethology Bulletin, 16(3). Photo by Peter LaFreniere. diverse disciplines during the 1970's and 80's, especially developmental psychology. (See Bill's review of Blurton-Jones, Ethological Studies of Child Behaviour, 1972)

"As a whole, the book is a good example of the growing trend to bridge the psychological and biological sciences. By making the psychologist aware of the power of evolutionary theory and its attendant methodology, many ethologists today hope to convince psychology that the revolution Darwin began continues to have deep relevance for understanding human behavior. Unlike many popular attempts to do this convincing, the present book takes a hard, no-nonsense line about the methodological problems that have to be overcome when researchers begin moving from animals to humans. For this reason alone, the present book is worthy of being in the invading forefront of responsible ethological research aimed at adding to our understanding of human behaviour."

Extract from Charlesworth W (1973) "Ethology: A new invasion" Review of "Ethological studies of child behaviour'(1972) N. Blurton-Jones (ed) CUP, New York in Contemporary Psychology 18(3), 106-107 
During this stage Bill's research highlighted the unique contribution of an ethological perspective to human cognitive development in a series of articles published in psychology journals and book chapters Charlesworth, (1973, 1975, 1976, 1979a, $1979 \mathrm{~b})$. After a period of broadcasting the arrival of Human Ethology to his colleagues in developmental psychology, Bill began to concentrate his energy on supporting the new discipline by publishing in it's flagship journal, Ethology and Sociobiology with a number of ethological observational studies of children. Later, after Ethology and Sociobiology abruptly changed direction and was renamed Human Behavior and Evolution, he withdrew his support. Instead he concentrated on supporting the Human Ethology Bulletin (now Human Ethology), ISHE's official journal, with a dozen publications, including his Presidential address in 1994. He continued to be active in ISHE long after his Presidency, with presentations at ISHE conferences, many book reviews for HEB and serving on the first Board of Trustees.

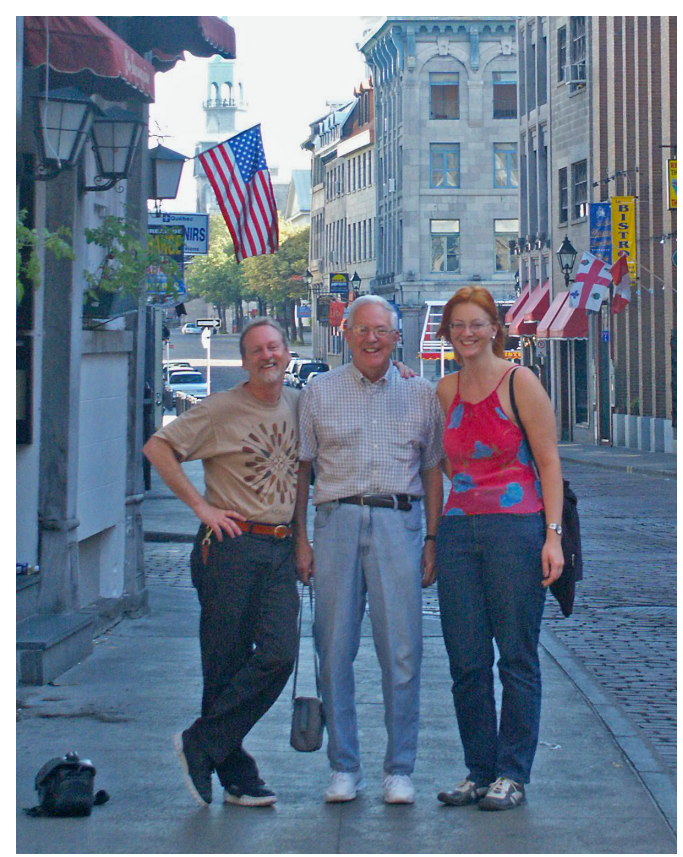

Picture 11: Peter LaFreniere, Bill Charlesworth, \& Astrid Juette. ISHE conference, Montreal 2002. Photo by Francisco Abati. Bill also remained the face of Human Ethology to the developmental community with a series of historical analyses detailing Darwin's seminal contribution to its early history and his abiding influence throughout the $20^{\text {th }}$ century (Charlesworth, 1985, 1992), He continued this role with a series of publications on how children generate and distribute resources with publications in developmental journals and books up to 2005 (Charlesworth, 2005).

Bill was my research advisor at ICD, University of Minnesota from 1978-82 during which time we collaborated on a number of studies. For the first two years we worked on his ongoing naturalistic research on problem-solving in young children. During this period we had many animated discussions about my interest in studying social interaction. I remember presenting my case to him that social behavior, by definition, was observable, while cognition was hidden from view. During these debates, Bill was never authoritarian or inflexible and he was eventually happy to join me on a series of studies on cooperation and competition among preschool children.

Part of Bill's genius as a research mentor was to "lead from behind", to coin a phrase. I plunged eagerly ahead with "my" naturalistic approach to social structures of peer groups, which was really already mainstream ethological work being published by human ethologists like Nick Blurton-Jones, Fred Strayer and others. Meanwhile, Bill returned to his earlier experimental training to come up with a completely original method to 
explore the problem of cooperation-competition that dovetailed perfectly with the naturalistic data I was collecting.

Thus began our most fruitful collaboration. Over the next decade we published a series of studies that combined field and laboratory methods to investigate the influence of dominance and friendship on behavior in a cooperative/competitive situation among preschool peers. After extensive naturalistic observation of the social structures of dominance, visual attention and affiliation in a number of preschool peer groups, we composed groups of four children each (two girls, two boys) and filmed them in a room containing a toy movie viewer (a resource) that required the assistance of two children to turn a crank and hold down a light switch in order for one child to view the movie. The beauty of this new experimental paradigm was that it modeled the fundamental distinction between human and non-human resource acquisition. Non-human animals forage for resources in their environment, whereas modern humans cooperate to generate their vital resources. They also compete in subtle ways, and the evidence for this is the unequal distribution of resources that we observe in human societies. We could now study the emergence of leadership styles and distributive justice in natural peer groups by manipulating their composition with respect to key variables of interest.

Using the new paradigm we were able to demonstrate that, as expected, dominant children were able to gain access to the viewer and use the resource more than lowerranked classmates. But dominant behavior alone could be spectacularly unsuccessful since obtaining the resource required the cooperation of at least two peers. At a group level of analysis, high status groups of friends used the resource much more effectively and more equitably than groups composed predominantly of low ranking children or non-friends. Friendship relations rather than specific affiliative behaviors in the situation were associated with high resource utilization. A mixture of quasi-agonistic and opportunistic behaviors led to high individual resource utilization; while overt agonistic behaviors were infrequent and unrelated to resource utilization. (Charlesworth \& LaFreniere, 1983, LaFreniere \& Charlesworth, 1983, 1987). Other studies using the movie-viewer analyzed gender differences and similarities. Groups of four boys or four girls were both effective and equally equitable, but they did this in very different ways, with girls being more verbal and boys more physical (Charlesworth \& Dzur, 1987). Bill then took the movie-viewer on a crosscultural tour in an effort to demonstrate the universality of our basic findings (Charlesworth, 2005).

This integration of field and laboratory studies, led to many theoretical discussions between us that highlighted the role of deception (one of my key interests at the time)

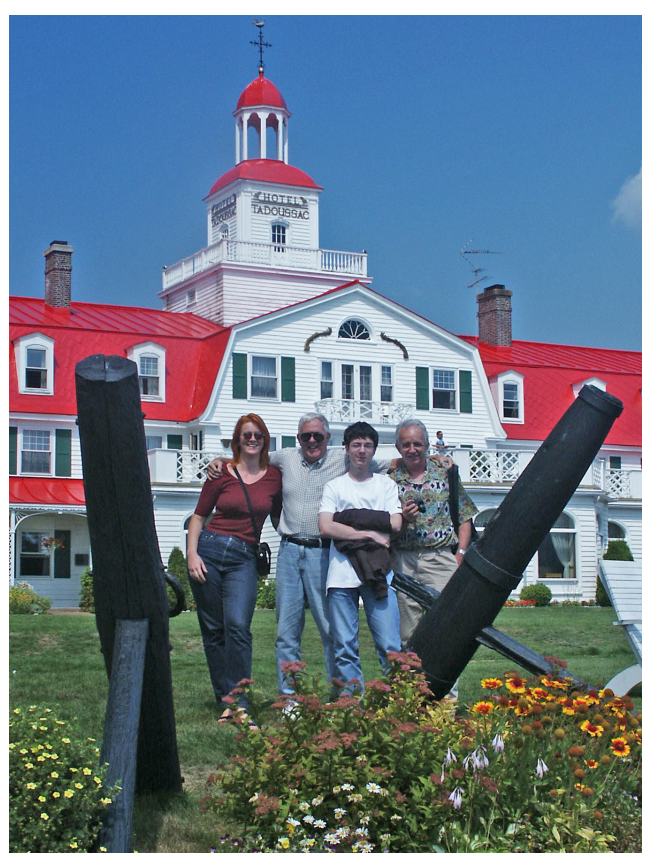

Picture 12: Whale watchers Astrid Jutte, Bill Charlesworth, Bennie \& Karl Grammer at the Hotel Tadoussac, June 2001. Originally published 2002 in Human Ethology Bulletin, 17 (3). 
and subsequently led to another one of Bill's seminal theoretical insights. In an influential paper, Bill introduced the idea that cooperation and competition were not polar opposites, but that cooperation was actually an effective form of competition (Charlesworth, 1996).

\section{The Other Side of Bill Charlesworth: The Life of the Party}

Writing about his father, Lord Randolph, Winston Churchill had this to say:

"His place in our political history is measured not by his words and actions, but by the impression which his personality made upon his contemporaries. This was intense ... He embodied that force, caprice and charm which so often springs from genius."

Reading this bit of history during Covid-19 instantly reminded me of Bill Charlesworth. I thought it appropriate to conclude this tribute with a few words on Bill's immeasurable contribution to the collegial friendships that define ISHE.

This charismatic quality of his was apparent to me the moment I met him. Bill had an inimitable way of captivating a small group that everyone around him thoroughly enjoyed. On so many occasions at ISHE gatherings around the world I watched him hold forth with his quick wit and intelligent charm, carrying the conversation to new heights sometimes of insight, other times to hilarity, often to both at the same time.

This playful quality was also apparent in the lab despite the serious work of behavioral coding. To conclude, below is a list of some of the crazy, but insightful, comments generated while working in our lab. This list was compiled by Bill himself decades ago and titled "Gems of apparent wisdom that came out of our lab".

"You have to roll along ways until you're perfectly round" (while showing coders one of the pebbles Bill collects)

"Stereotypes are like talking toddlers. They both say more than they should, but we still like living with them"

"An adolescent is a person who would like to write a great novel but can't find a pencil sharpener."

"Cynics love to be described as free thinking because they don't have to pay for it."

"Many think about becoming famous but can't fill out the form right."

"If everyone lit their Christmas tree at the same time, the world would ... it's too overwhelming to contemplate. Just don't do it, Okay?"

"To talk with charisma about one's research is actually more fun than doing the research and also gets one more invitations to other places, which, in winter, ca be a great advantage in Minnesota." 
"ICD faculty never change their guiding scientific principle which is that the essence of intelligent behavior is change."

"It is a hard-proven empirical fact that more than $96 \%$ of faculty everywhere believe they are above average."

And a favorite of ISHE members, "Follow the duck, not your theory of the duck."

\section{SELECTED REFERENCES}

\section{Early experimental research}

Charlesworth, W. R. (1964). The instigation and maintenance of curiosity behavior as a function of surprise versus novel and familiar stimuli. Child Development, 35(4), 1169-1186. DOI

Charlesworth, W. R., \& Zahn, C. (1966). Reaction time as a measure of comprehension of the effects produced by rotation on objects. Child Development, 37(2), 253-268. DOI

Charlesworth, W. R. (1966). Persistence of orienting and attending behavior in infants as a function of stimuli locus uncertainty. Child Development, 37(3), 473-491. DOI

Charlesworth, W. R. (1969). The role of surprise in cognitive development. In D. Elkind \& J. H. Flavell (Eds.), Studies in cognitive development: Essays in honor of Jean Piaget. New York: Oxford University Press.

\section{Transition to Human Ethology}

Charlesworth, W. R. (1973). Ethology: A new invasion. Contemporary Psychology, 18(3), 106-107. DOI

Charlesworth, W. R., \& Kreutzer, M. A. (1973). Facial expressions of infants and children. In P. Ekman (Ed.), Darwin and facial expression: A century in review (pp. 91-168). New York: Academic Press.

Charlesworth, W. R. (1975, January). Developmental psychology and human ethology, SRCD Newsletter 4-6, 11.

Charlesworth, W. R. (1976). Human intelligence as adaptation: An ethological approach. In L. Resnick (Ed.), The nature of intelligence (pp. 147-168). Hillsdale, NJ: Lawrence Erlbaum Associates.

Charlesworth, W. R. (1978, April). Ethology: Understanding the other half of intelligence. Social Science Information, 7(2), 231-277. DOI

Charlesworth, W. R. (1979a). An ethological approach to studying intelligence. Human Development, 22(3), 212-216. DOI

Charlesworth, W. R. (1979b). Ethology: Understanding the other half of intelligence. In M. von Cranach, K. Foppa, W. Lepenies, \& D. Ploog (Eds.), Human ethology: Claims and limits of a new discipline (pp. 491-519). Cambridge: Cambridge University Press.

Charlesworth, W. R. (1982). An ethological approach to research on facial expressions. In C. E. Izard (Ed.), Measurement of emotions in infants and children (pp. 317-334). New York: Cambridge University Press.

Henderson, B., Charlesworth, W. R., \& Gamradt, J. (1982). Children's exploratory behavior in a novel field setting. Ethology and Sociobiology, 3(2), 93-99. DOI 
Charlesworth, W. R. (1983). An ethological approach to cognition. In C. Brainerd (Ed.), Recent Advances in Cognitive-Developmental Theory (pp. 237-258). New York: Springer-Verlag.

\section{Ethological research on cooperation and competition for resources}

LaFreniere, P., \& Charlesworth, W. R. (1983). Dominance, affiliation, and attention in a preschool group: A nine-month longitudinal study. Ethology and Sociobiology, 4(2), 55-67. DOI

Charlesworth, W. R., \& LaFreniere, P. (1983). Dominance, friendship, and resource utilization in preschool children's groups. Ethology and Sociobiology, 4(3), 175-186. DOI

LaFreniere, P. J., \& Charlesworth, W. R. (1987). Effects of friendship and dominance status on preschooler's resource utilization in a cooperative/competitive situation. International Journal of Behavioral Development, 10(3), 345-358. DOI

Charlesworth, W. R., \& Dzur, C. (1987). Gender comparisons of preschoolers' behavior and resource utilization in group problem solving. Child Development, 58(1), 191-200. DOI

Charlesworth, W. R. (1988). Resources and resource acquisition behavior during ontogeny. In K. MacDonald (Ed.), Sociobiological perspectives on human development (pp. 24-77). New York: Springer-Verlag. DOI

Charlesworth, W. R. (1996). Cooperation as competition: Contributions to a developmental and evolutionary model. International Journal of Developmental Psychology, 19(1), 25-39. $\underline{\text { DOI }}$

Charlesworth, W. R. (2005). Strategies for resource and reproductive competition in the socialization of Amish and Gypsy children. In R. L. Burgess \& K. MacDonald (Eds.), Evolutionary Perspectives on Human Development (pp. 359-380). London: Sage Publications. $\underline{\text { DOI }}$

\section{The wider view}

Charlesworth, W. R. (1985). Darwin and developmental psychology: From the proximate to the ultimate. Human Development, 29, 1-4, 22-35.

Charlesworth, W. R. (1992). Darwin and developmental psychology. Developmental Psychology, 28(1), 5- 16. DOI

Charlesworth, W. R. (1994, August 9). Human ethology: A good idea for the behavioral sciences and society. Presidential Inaugural Address International Society for Human Ethology.

In addition to his scientific publications, William R. Charlesworth is the author of Haiku: A Point of Light (2004) and other volumes of poetry. 